\section{Alcohol outlets availability in school neighborhoods and alcohol use among adolescents}

\author{
Disponibilidade de locais de venda de álcool na \\ vizinhança de escolas e consumo de álcool \\ entre adolescentes
}

Disponibilidad de establecimientos para la venta de alcohol en las cercanías de las escuelas y consumo de alcohol entre adolescentes
Loren Salazar Cardoza 1

Christiane Opuszka Machado 1

Clara Telles dos Santos 1

Doroteia Aparecida Höfelmann 1

\begin{abstract}
This cross-sectional study investigated the association between alcohol use by adolescents and the availability of alcohol outlets in the neighborhood of public schools. We collected primary data including variables at individual and school neighborhood level. Multilevel logistic regression was used to estimate odds ratio $(\mathrm{OR})$ with a 95\% confidence interval (95\%CI) for alcohol use with the exposure variables. A total of $18.4 \%$ (95\%CI: 13.2; 24.1) of adolescents reported using alcohol, which was associated with variables on the individual level such as being 18 years or older, working, and having previously smoked. Lower alcohol use was observed among adolescents from schools that were located $250 \mathrm{~m}$ or more from alcohol outlets $(\mathrm{OR}=0.29 ; 95 \% \mathrm{CI}: 0.17 ; 0.48)$. Actions to reduce the use of alcohol among adolescents should take student's and school neighborhood's characteristics into account.
\end{abstract}

Underage Drinking; Neighborhood; Multilevel Analysis

\section{Correspondence}

L. S. Cardoza

Universidade Federal do Paraná.

Rua Padre Camargo 280, 3o andar, Curitiba, PR 80060-240,

Brasil.

loren.scardoza@gmail.com

1 Universidade Federal do Paraná, Curitiba, Brasil. 


\section{Introduction}

Alcohol is the most used psychotropic substance in the world 1 and generally its use starts during adolescence 2 . It is considered a risk factor for non-transmissible chronic diseases, and according to the World Health Organization it was partially or fully associated with $6 \%$ of deaths worldwide 3 .

In Latin America and the Caribbean one in every three students between 13 and 15 years reported having used alcohol at least once over the last month, with South America having a higher use rate (37.7\%) than the Caribbean (24.6\%). The South American countries that presented the highest percentages of use in 2015 among adolescents between 13 and 15 years were Colombia (57.5\%), Argentina (51\%), Ecuador (30\%) and Chile (28.8\%) 4.

In Brazil, the most comprehensive study about alcohol consumption among adolescents is the Study of Cardiovascular Risks in Adolescents (ERICA), conducted in 2013-2014, which showed that one in every five adolescents consumed alcohol at least once in the last 30 days and $24.1 \%$ experimented alcohol for the first time at 12 years old 5 .

Additionally, data from the Brazilian Adolescent School-based Health Survey (PeNSE) in 2015 show a prevalence of alcohol use in Brazilian adolescents between 13 and 15 years old of 24.1\%, and of $34.8 \%$ among those 16 to 17 years old 6 .

Alcohol is a controversial subject in academic and social environments 7, as well as complex, considering that the sale of alcohol to those under 18 years old in Brazil is forbidden by law (Law $n$. 9,294 of July 15, 1996). Even though adolescents under 18 find restrictions in their access to alcoholic beverages, they report that their main source are parties, friends, markets and family, from most common to less common 6 . This can be explained by the social acceptance of alcohol use and by the lack of enforcement of the laws that forbid the sale of alcohol to minors 7 .

An increasing number of studies are being conducted to verify the many factors that can influence alcohol use. The majority of the research identified an association with adolescents' characteristics, such as: being older, male and having higher income; as well as family factors, such as: parents' divorce, lack of family support, and use and abuse of alcohol by their caretakers 8,9,10,11,12.

Aside from these factors, aspects related to the environment have gained relevance in such investigations, such as: the socioeconomic status of the neighborhood, alcohol outlet availability, security perception, and the perception of substance abusers' activities in the neighborhood. Analysis of the availability of alcohol outlets has been done in two different ways: by outlet density (total number of establishments in a predetermined area) and the proximity between the outlets and the school or student's residence 13,14. Alcohol outlets are classified in two different types: on-premises alcohol outlet and off-premises alcohol outlet.

A review 15 indicated that the majority of publications evaluating the association between the availability of alcohol outlets and their use by adolescents were conducted in the United States. Part of these studies found strong association between the availability of alcohol beverage, lifetime use, and heavy drinking 16,17,18, while other studies found no association 14,19 .

The existence of information about the geographical distribution of alcohol outlets plays an important role in supporting decision-making regarding land use and occupation, as well as public health policies and intervention, as one of the ways of lowering alcohol use by adolescents is to reduce the exposure and the availability of stores that sell it 14,19 .

Research conducted in other countries, including South America, is important, given that economic, social and cultural differences can influence the result, because the availability of information and legislation varies, even within the same country. An example is the fact that in Brazil certain cities have more strict regulations regarding alcohol use than others. As such, this study investigated the association between alcohol use by adolescents and the availability of alcohol outlets in the neighborhoods of public schools. 


\section{Methods}

A cross-sectional study was conducted with primary data collection as part of the project Overweight and Characteristics of the School Environment in Students of Curitiba, Paraná, that investigated the association of overweight with socioeconomic, demographic, school environment characteristics and health-related behavior in adolescents attending public schools in Curitiba, Paraná State, Brazil.

The study took place in the city of Curitiba, which comprises 10 administrative regions and 76 neighborhoods 20. It is the most populous city of the state with an estimated population of 1,893,997 inhabitants in 2016 (Instituto Brasileiro de Geografia e Estatística. https://cidades.ibge.gov.br/brasil/ $\mathrm{pr} /$ curitiba/panorama, accessed on Apr/2019) and, according to the last census data, adolescents (10 to 19 years old) constitute $15.4 \%$ of the total population (Instituto Brasileiro de Geografia e Estatítica. http://www.ibge.gov.br, accessed on Apr/2019). The Human Development Index (HDI) for 2010 was considered high (0.823) according to the United Nations program for development criteria, nonetheless the HDI for neighborhoods such as Tatuquara, Vila Torres (0.623) and Água Verde (0.956) express the socioeconomic differences that exist within the city 20 .

\section{Population}

The study was conducted with adolescents regularly enrolled from the 6th grade until the last high school year during 2016 in Curitiba's public schools.

\section{Sample}

Sample size was calculated based on the number of students enrolled from the 6th grade until of the last high school year during the day in Curitiba, amounting to 110,238 students. To maximize sample size and allow investigation of other outcomes being studied, an unknown outcome prevalence of $50 \%$ was used, margin of error of $4 \%$ and a $95 \%$ confidence interval $(95 \% \mathrm{CI})$, resulting in a sample size of 597 adolescents.

To participate in the study, the schools were randomly drawn from a list of all eligible institutions (30 out of 160, not including those exclusive for special or indigenous education) and, because of that, the design effect of 2 was taken into consideration, doubling the estimated sample size $(\mathrm{n}=1,194)$. A total of $20 \%$ was added to correct eventual losses and refusals, resulting in a sample of 1,433 students. With this proposed sample size, it was possible to identify a prevalence ratio of 1.14 , equivalent to a prevalence of $50 \%$ among the exposed and $44 \%$ for the non-exposed, with a power of $80 \%$ and a level of $95 \%$ of confidence.

After the drawing of participating schools, a drawing was done for the school year that would be evaluated in each school, trying to make a proportional distribution of the number of each school year. When the number of students in the selected classroom was higher than the number of the sample size, the students were selected based on an alphabetic list, in an alternating order, starting from the first student in the list. When it was necessary to evaluate two or more classrooms, the same procedure was repeated, starting with the second student. This procedure was repeated for the other classrooms, always alternating the names drawn between the first and the second in the alphabetic list.

\section{Measures}

This study used two different surveys, one to evaluate the students and another to evaluate the stores.

\section{- Students}

The students received a printed questionnaire to fill in the classroom with the help of the researchers. It included multiple-choice questions and had an average duration of 30 minutes.

The variables collected included demographic information, school shift, work- and health-related behavior, separated in three blocks: (1) demographic: gender (male, female) and age (10-14 years, 15-17 years, 18 years and older); (2) school shift: morning, afternoon, intermediate or full time; work 
(no, yes); (3) health-related behavior: ever tried smoking (no, yes), supervised physical activity (no, yes) and alcohol use [(i) days of use in an average week, (ii) number of doses during the days of use in an average week. Examples were offered to show what a dose of alcohol using the most consumed beverages by adolescents is (i.e. a can of beer, a glass of wine or a dose of a distilled alcoholic beverage)] 21,22.

\section{- Establishments in the schools neighborhoods}

The neighborhoods of the 30 selected schools were evaluated. The area was defined as a circle around the school with a radius of $250 \mathrm{~m}$, amounting to an area of $196,350 \mathrm{~m}^{2}$ and about 10 minutes' walk around the perimeter. The area was defined based on the possibility of accomplishment in terms of time and team of researchers.

The streets inside the area were traveled by foot. The evaluation was done in two steps: (1) in loco mapping, which included the identification of the stores that sold any type of alcohol as a goal, and (2) applying the survey to evaluate the availability of alcoholic beverages.

Due to the nonexistence of a specific instrument to evaluate the availability of alcohol outlets translated and validated in Brazilian Portuguese, one was developed by the researchers. It evaluated the following aspects: types of stores that sold any kind of alcoholic beverage; opening hours; types of drinks available considering those grouped by World Health Organization 23 (beer, wine and distilled beverage; prices and corresponding sizes; presence of alcoholic beverage advertisement; presence of a warning sign forbidding alcohol sale to minors (under 18 years). The evaluation of these places happened during the time the students that were selected for the research attended school (morning, afternoon or fulltime/intermediate shift).

For posterior analysis, the stores were classified according to the criteria employed in other international studies: on-premises alcohol outlet (restaurants, bars, cafés, dinners, pizza parlors, pastry shops, food trucks) and off-premises alcohol outlet (convenience stores, gas stations, neighborhood markets, supermarkets, groceries, bakeries and drink distributors 15.

\section{Variables}

The outcome variable was alcohol use, taken from the habitual frequency of weekly use and the number of doses reported, meaning at least one dose consumed in at least one day during an average week.

The independent variables were separated in three blocks: (1) characteristics at the individual level (gender, age, work, school shift, having smoked before and supervised physical activity); (2) socioeconomic characteristics of the school's neighborhood; and (3) characteristics of the school's neighborhood.

Alcohol availability variables were taken from the data collected in the outlets evaluated in the schools neighborhoods, categorized in terciles: number of alcohol outlets $(0 ; 1 ; 2-7)$, number of cigarette outlets $(0-1 ; 2-3 ; 4-7)$, number of both alcohol and cigarette outlets $(0 ; 1 ; 2-4)$, number of onpremises alcohol outlets $(0 ; 1-2 ; 3-10)$, number of off-premises alcohol outlets (0-1;2-3;4-8), number of outlets with alcohol advertisement $(0 ; 1 ; 2-7)$, number of outlets with a warning sign forbidding alcohol sale to minors $(1 ; 2 ; 3)$, school size (small: until 499 students; medium: 500-999; big: 1,000 or more), distance of the closest alcohol outlet to school (categories: 0-100m; 101-250m;251m or more) and distance from school to city center (distance from school to ground zero: $1.6-5.6 \mathrm{~km} ; 5.7-8.2 \mathrm{~km}$; 8.3 or more).

To characterize the school's neighborhood, data from the unities of human development (UHD) was used, defined from the school's addresses. The UHD is a classification used by Atlas Brazil and represents regions with a high socioeconomic homogeneity in order to depict metropolitan inequalities more clearly 24. They respect IBGE (Brazilian Institute of Geography and Statistics) criteria in terms of socioeconomic homogeneity and contiguity and are areas recognized by the residing population (identity). In Curitiba, the UHDs correspond to the grouping of census sectors (smaller operative administrative unit for census). Measures of demographic density, distribution of inhabitant per square kilometer (inhabitants/km2: 163.8-3,577.8; 3,577.9-4,556.6; 4,556.7-11,579.1) of household income per capita (2010), calculated as the total household income divided per person living in the residence (BRL 439.7-853.0; 854.0-2,104.6; 2,104.7-4,645.6) 13,24 were obtained and distributed in terciles. 


\section{Analysis}

Descriptive analysis was performed with absolute values and percentages. Multilevel logistic regression (at the individual level and neighborhood level) was employed to estimate the odds ratio (OR) for alcohol use with the exposure variables and $95 \% \mathrm{CI}$, and p-values were obtained from the Wald's test. A hierarchical model of the factors related to alcohol use was employed and structured into three blocks: the first one composed of variables related to adolescents; the second was composed of variables about the schools neighborhood's socioeconomic conditions, and lastly, the third was composed of variables related to schools' neighborhoods and the schools' themselves (Figure 1). The area considered for a schools' neighborhood did not overlap between schools, and as such each neighborhood was comprised of only one school, and the school and school neighborhood variables were considered at same level for analysis.

The analysis considered the sample weights and the study's design (survey). The sample weights were estimated by the inverse probability of participating in each sample unity: (1) schools; (2) classroom; (3) student $(\mathrm{F} 1 / \mathrm{f} 1 * \mathrm{~F} 2 / \mathrm{f} 2 * \mathrm{~F} 3 / \mathrm{f} 3)$ (pweight). Furthermore, the estimated variability of the measurements due to variations in the schools was calculated by the intraclass correlation coefficient (ICC) using the equation icc $=\operatorname{var}(\mathrm{u} 0) /\left[\operatorname{var}(\mathrm{u} 0)+\varpi^{2} / 3\right]$ as measures to adjust the model: Akaike information criterion (AIC) and the Bayesian information criterion (BIC). Analysis were performed in the software Stata version 14 (https://www.stata.com).

\section{Ethical aspects}

The research project was approved by the Ethics Committee of Research on Human Beings of Universidade Federal do Paraná under protocol number Certificate of Presentation for Ethical Appreciation (CAAE): 4085215.1.0000.0102 and approved by the report n. 142661, in 26 of February of 2016, which was sent to the Superintendence of Educational Development (SUDE) of Paraná afterwards for analysis of project viability. The participants' consent was verbally informed after the research and its procedures were explained, and contact information was available when requested.

\section{Results}

A total of 1,623 adolescents were invited to take part in the research, of which 1,232 participated and 1,146 conformed the analytical sample of the study. The adolescents were evenly distributed according to gender ( $50.8 \%$ male), only $2 \%$ were 18 years and older and $57.4 \%$ attended school during the morning shift; $12.4 \%$ reported working. The majority of the participants declared not smoking (94.3\%) and not engaging in supervised physical activity (72.9\%). Among the adolescents $18.4 \%$ (95\%CI: 13.2 ; 24.1) reported having used alcohol (Table 1). The mean number of doses used by those who reported weekly use was three, ranging from 1 to 35 .

It was observed that $40 \%(\mathrm{n}=12)$ of the schools had 1,000 or more students and were situated in neighborhoods with a mean per capita income of BRL 854.0-2,104.6 (Table 1). Among the evaluated neighborhoods $16.7 \%(\mathrm{n}=5)$ did not have any alcohol outlet open during school hours, in a radius of $250 \mathrm{~m}$ from the school; $83.4 \%(\mathrm{n}=25)$ of the schools had at least one alcohol outlet in the evaluated area and half of them $(n=15)$ had alcohol outlets that did not present any warning sign forbidding the sale of alcohol to minors. (Table 1).

There was no significant difference of alcohol use for both genders. Adolescents 18 years or older had 6.35 (95\%CI: $2.17 ; 18.54)$ more chances of using alcohol compared to those younger. Higher odds of using alcohol were also present in those who worked $(\mathrm{OR}=2.12 ; 95 \% \mathrm{CI}$ : $1.18 ; 3.79)$ and that had smoked before ( $\mathrm{OR}=8.32 ; 95 \% \mathrm{CI}: 4.37 ; 14.84)$. There was an association between alcohol use and a higher density of on-premises alcohol outlets (Table 2).

Considering the socioeconomic characteristics of the evaluated neighborhoods, we observed a higher chance of alcohol use among the adolescents that attended schools in places where the UDHs had a higher demographic density $(\mathrm{OR}=2.91 ; 95 \% \mathrm{CI}$ : 1.16; 7.32), and a higher income $(\mathrm{OR}=2.79$; $95 \%$ CI: $1.27 ; 6.10)$. After adjustment, the variables of the individual level did not have a significant association with income (Table 2). 


\section{Figure 1}

Theoretical framework of factors related to alcohol use by adolescents, structured in block for the analysis of alcohol use by adolescents of public schools. Curitiba, Paraná State, Brazil.

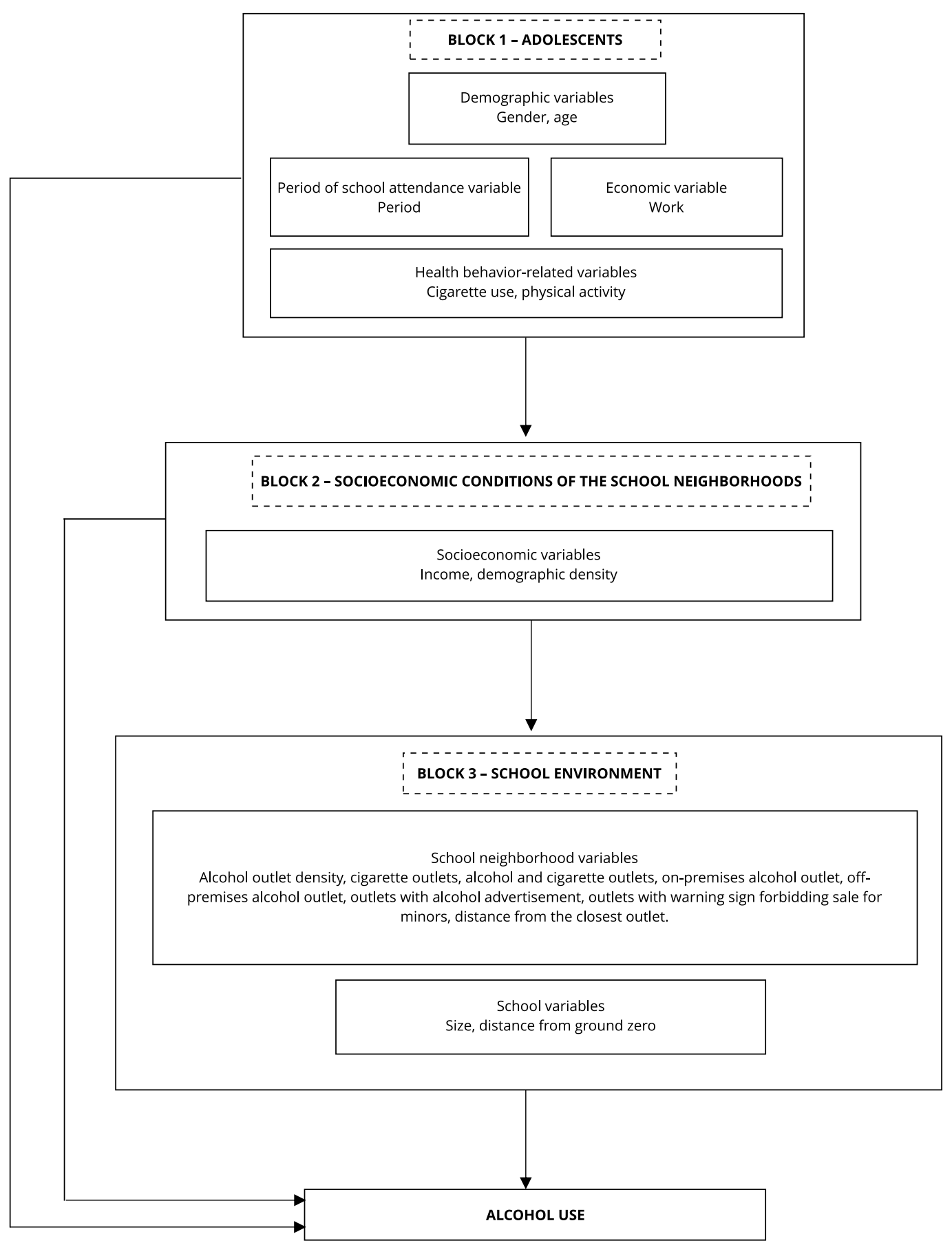


Table 1

Description of the demographic characteristics, work, period and health-related behavior in adolescents of public schools and of school neighborhood characteristics. Curitiba, Paraná State, Brazil, 2016-2017.

\begin{tabular}{|c|c|c|}
\hline Variables & $\mathbf{n}$ & $\%$ \\
\hline \multicolumn{3}{|c|}{ Adolescents level $(n=1.146)$ * } \\
\hline \multicolumn{3}{|l|}{ Gender } \\
\hline Male & 589 & 50.8 \\
\hline Female & 557 & 49.2 \\
\hline \multicolumn{3}{|l|}{ Age (years) } \\
\hline $10-14$ & 691 & 61.3 \\
\hline $15-17$ & 431 & 36.7 \\
\hline 18 and older & 24 & 2.0 \\
\hline \multicolumn{3}{|l|}{ Work } \\
\hline No & 998 & 87.6 \\
\hline Yes & 148 & 12.4 \\
\hline \multicolumn{3}{|l|}{ Period } \\
\hline Morning & 684 & 57.4 \\
\hline Afternoon & 355 & 34.4 \\
\hline Full-time & 107 & 8.2 \\
\hline \multicolumn{3}{|c|}{ Supervised physical activity } \\
\hline Yes & 319 & 27.1 \\
\hline No & 827 & 72.9 \\
\hline \multicolumn{3}{|l|}{ Smoking } \\
\hline No & 1076 & 94.3 \\
\hline Yes & 70 & 5.7 \\
\hline \multicolumn{3}{|l|}{ Alcohol use ** } \\
\hline No & 942 & 81.6 \\
\hline Yes & 204 & 18.4 \\
\hline \multicolumn{3}{|c|}{ School neighborhood level (socioeconomic indexes) $(n=30) * \star *$} \\
\hline \multicolumn{3}{|c|}{ Demographic density (inhabitants $/ \mathrm{km}^{2}$ ) } \\
\hline $163.8-3,577.8$ & 9 & 30.0 \\
\hline $3,577.9-4,556.6$ & 10 & 33.3 \\
\hline $4,556.7-11,579.1$ & 11 & 36.7 \\
\hline \multicolumn{3}{|c|}{ Per capita income in 2010 (BRL) } \\
\hline 439.7-853.0 & 10 & 33.3 \\
\hline $854.0-2,104.6$ & 12 & 40.0 \\
\hline $2,104.7-4,645.6$ & 8 & 26.7 \\
\hline \multicolumn{3}{|c|}{ Alcohol outlet density } \\
\hline 0 & 5 & 16.7 \\
\hline 1 & 2 & 6.7 \\
\hline $2-7$ & 23 & 76.6 \\
\hline \multicolumn{3}{|c|}{ Cigarette outlet density } \\
\hline $0-1$ & 14 & 46.7 \\
\hline $2-3$ & 12 & 40.0 \\
\hline $4-7$ & 4 & 13.3 \\
\hline \multicolumn{3}{|c|}{ Alcohol and cigarette outlet density } \\
\hline 0 & 15 & 50.0 \\
\hline 1 & 11 & 36.7 \\
\hline $2-4$ & 4 & 13.3 \\
\hline
\end{tabular}

(continues) 
Table 1 (continued)

\begin{tabular}{|c|c|c|}
\hline Variables & $\mathbf{n}$ & $\%$ \\
\hline \multicolumn{3}{|c|}{ On-premise alcohol outlets } \\
\hline 0 & 12 & 40.0 \\
\hline $1-2$ & 9 & 30.0 \\
\hline $3-10$ & 9 & 30.0 \\
\hline \multicolumn{3}{|c|}{ Off-premises alcohol outlets } \\
\hline $0-1$ & 12 & 40.0 \\
\hline $2-3$ & 9 & 30.0 \\
\hline $4-8$ & 9 & 30.0 \\
\hline \multicolumn{3}{|c|}{ Outlets with alcohol advertisement } \\
\hline 0 & 12 & 40.0 \\
\hline 1 & 10 & 33.3 \\
\hline $2-7$ & 8 & 26.7 \\
\hline \multicolumn{3}{|c|}{ Outlets with warning sign forbidding sale for minors } \\
\hline 1 & 8 & 26.7 \\
\hline 2 & 1 & 3.3 \\
\hline 3 & 1 & 3.3 \\
\hline \multicolumn{3}{|c|}{ Closest alcohol outlet (m) } \\
\hline $0-100$ & 11 & 36.7 \\
\hline $101-250$ & 10 & 33.3 \\
\hline 251 or more & 9 & 30.0 \\
\hline \multicolumn{3}{|c|}{ School size (number of students) } \\
\hline Less than 499 & 5 & 16.7 \\
\hline $500-999$ & 13 & 43.3 \\
\hline 1,000 or more & 12 & 40.0 \\
\hline \multicolumn{3}{|c|}{ Distance from city ground zero $(\mathrm{km})$} \\
\hline $1.6-5.6$ & 11 & 36.7 \\
\hline $5.7-8.2$ & 9 & 30.0 \\
\hline 8.3 or more & 10 & 33.3 \\
\hline
\end{tabular}

* Corrected for sample weight and study design;

** Alcohol use was considered as having used one dose at least one day in an average week;

*** Simple counting, the absolute number and the percentages were not corrected for simple weight and design effect.

\section{Table 2}

Association of alcohol use with adolescents characteristics level and school's neighborhood level in public schools. Curitiba, Paraná State, Brazil, $2016-2017$.

\begin{tabular}{|c|c|c|c|c|c|c|c|}
\hline Variables & Yes [n (\%)] & OR not adjusted $(95 \% \mathrm{Cl})$ & p-value * & OR adjusted $(95 \% \mathrm{Cl})$ & p-value * & ICC $(95 \% \mathrm{Cl})$ & AIC \\
\hline Empty model & & & & & & $0.18(0.09 ; 0.30)$ & \\
\hline Adolescent level & & & & & & & $1,062.45$ \\
\hline \multicolumn{8}{|l|}{$(n=1.146)$} \\
\hline Demographics & & & & & & $0.06(0.02 ; 0.17)$ ** & \\
\hline Gender & & & 0.789 & & 0.350 & & $1,040.69$ \\
\hline Male & $98(16.6)$ & 1.00 & & 1.00 & & & \\
\hline Female & $106(20.4)$ & $1.05(0.73 ; 1.51)$ & & $1.20(0.82 ; 1.76)$ ** & & & \\
\hline Age (years) & & & 0.000 & & 0.000 & & \\
\hline $10-14$ & $67(9.8)$ & 1.00 & & 1.00 & & & \\
\hline $15-17$ & $126(31.3)$ & $3.18(1.70 ; 5.95)$ & & $2.93(1.66 ; 5.17) * *$ & & & \\
\hline 18 and older & $11(47.5)$ & $6.35(2.17 ; 18.54)$ & & $5.27(1.74 ; 15.98) * *$ & & & \\
\hline
\end{tabular}

(continues) 
Table 2 (continued)

\begin{tabular}{|c|c|c|c|c|c|c|c|}
\hline Variables & Yes [n (\%)] & OR not adjusted $(95 \% \mathrm{CI})$ & p-value * & OR adjusted $(95 \% \mathrm{Cl})$ & p-value * & ICC $(95 \% \mathrm{CI})$ & AIC \\
\hline Period & & & 0.004 & & 0.014 & $0.03(0.01 ; 0.13) * * *$ & $1,011.27$ \\
\hline Morning & $161(25.7)$ & 1.00 & & 1.00 & & & \\
\hline Afternoon & $39(10.1)$ & $0.38(0.21 ; 0.68)$ & & $0.64(0.39 ; 1.03) * \star *$ & & & \\
\hline Full-time & $4(3.0)$ & $0.10(0.02 ; 0.66)$ & & $0.25(0.07 ; 0.88) * \star \star$ & & & \\
\hline Work & & & 0.013 & & 0.010 & & \\
\hline No & $151(15.7)$ & 1.00 & & 1.00 & & & \\
\hline Yes & $53(37.7)$ & $2.12(1.18 ; 3.79)$ & & $2.10(1.20 ; 3.61) * \star \star$ & & & \\
\hline \multicolumn{8}{|l|}{$\begin{array}{l}\text { Health related } \\
\text { behaviors }\end{array}$} \\
\hline Smoke & & & 0.000 & & 0.000 & $0.03(0.01 ; 0.15) \#$ & 927.15 \\
\hline No & $161(15.7)$ & 1.00 & & 1.00 & & & \\
\hline Yes & $43(63.8)$ & $8.32(4.37 ; 14.84)$ & & $7.50(4.12 ; 13.63)$ \# & & & \\
\hline $\begin{array}{l}\text { Supervised } \\
\text { physical activity }\end{array}$ & & & 0.087 & & 0.057 & & \\
\hline Yes & $134(16.8)$ & 1.00 & & 1.00 & & & \\
\hline No & $70(23.0)$ & $1.57(0.93 ; 2.65)$ & & $1.63(0.99 ; 2.71)$ \# & & & \\
\hline $\begin{array}{l}\text { School } \\
\text { neighborhood level } \\
\text { (socioeconomic } \\
\text { indexes) }(n=30)\end{array}$ & & & & & & & \\
\hline $\begin{array}{l}\text { Demographic } \\
\text { density (inhabitants/ } \\
\mathrm{km}^{2} \text { ) }\end{array}$ & & & 0.022 & & & $0.01(0.00 ; 0.30)$ & 927.43 \\
\hline $163.8-3,577.8$ & $44(14.0)$ & 1.00 & & 1.00 & & & \\
\hline $3,577.9-4,556.6$ & $70(16.2)$ & $1.64(0.63 ; 4.28)$ & & 1.09 (0.60; 1.90) \#\# & & & \\
\hline $\begin{array}{l}4,556.7- \\
11,579.1\end{array}$ & $90(23.6)$ & $2.91(1.16 ; 7.32)$ & & $1.73(1.00 ; 2.90)$ \#\# & & & \\
\hline $\begin{array}{l}\text { Per capita income in } \\
2010 \text { (BRL) }\end{array}$ & & & 0.017 & & & & \\
\hline 439.7-853.0 & $54(13.2)$ & 1.00 & & 1.00 & & & \\
\hline $854.0-2,104.6$ & $62(14.5)$ & $1.13(0.49 ; 2.59)$ & & $1.23(0.70 ; 2.04) \# \#$ & & & \\
\hline $2,104.7-4,645.6$ & $88(18.4)$ & $2.79(1.27 ; 6.10)$ & & $1.54(0.80 ; 2.74) \# \#$ & & & \\
\hline $\begin{array}{l}\text { School size (number } \\
\text { of students) }\end{array}$ & & & 0.175 & & 0.003 & $\S$ & 918.98 \\
\hline Less than 499 & $26(16.3)$ & 1.00 & & 1.00 & & & \\
\hline $500-999$ & $68(14.8)$ & $0.87(0.33 ; 2.30)$ & & $1.29(0.75 ; 2.23)$ \#\#\# & & & \\
\hline 1,000 or more & $110(21.2)$ & $1.69(0.33 ; 2.30)$ & & 1.87 (1.10; 3.18$)$ \#\#\# & & & \\
\hline $\begin{array}{l}\text { Alcohol outlet } \\
\text { density }\end{array}$ & & & 0.619 & & & & \\
\hline 0 & $75(17.8)$ & 1.00 & & & & & \\
\hline 1 & $81(22.0)$ & $1.71(0.66 ; 4.43)$ & & & & & \\
\hline $2-7$ & 48 (15.9) & $1.20(0.47 ; 3.07)$ & & & & & \\
\hline $\begin{array}{l}\text { Cigarette outlet } \\
\text { density }\end{array}$ & & & 0.760 & & & & \\
\hline $0-1$ & $89(16.0)$ & 1.00 & & & & & \\
\hline $2-3$ & $95(23.7)$ & $1.71(0.73 ; 3.82)$ & & & & & \\
\hline $4-7$ & $20(13.2)$ & $0.82(0.22 ; 3.09)$ & & & & & \\
\hline
\end{tabular}

(continues) 
Table 2 (continued)

\begin{tabular}{|c|c|c|c|c|c|c|c|}
\hline Variables & Yes [n (\%)] & OR not adjusted $(95 \% \mathrm{Cl})$ & p-value * & OR adjusted $(95 \% \mathrm{Cl})$ & p-value * & ICC $(95 \% \mathrm{CI})$ & AIC \\
\hline $\begin{array}{l}\text { Alcohol and } \\
\text { cigarette outlet } \\
\text { density }\end{array}$ & & & 0.758 & & & & \\
\hline 0 & $117(19.6)$ & 1.00 & & & & & \\
\hline 1 & $64(16.3)$ & $0.90(0.42 ; 1.96)$ & & & & & \\
\hline $2-4$ & $23(18.5)$ & $1.43(0.49 ; 4.18)$ & & & & & \\
\hline $\begin{array}{l}\text { On-premise alcohol } \\
\text { outlets }\end{array}$ & & & 0.048 & & & & \\
\hline 0 & $66(12.5)$ & 1.00 & & & & & \\
\hline $1-2$ & $57(18.7)$ & $1.79(0.73 ; 4.36)$ & & & & & \\
\hline $2-7$ & $81(24.0)$ & $2.48(1.00 ; 6.15)$ & & & & & \\
\hline $3-10$ & $48(15.9)$ & $1.20(0.47 ; 3.07)$ & & & & & \\
\hline \multicolumn{8}{|l|}{$\begin{array}{l}\text { Off-premises alcohol } \\
\text { outlets }\end{array}$} \\
\hline $0-1$ & $70(17.6)$ & 1.00 & & & & & \\
\hline $2-3$ & $75(23.6)$ & $1.95(0.77 ; 4.95)$ & & & & & \\
\hline $4-8$ & $59(15.3)$ & $1.22(0.45 ; 3.29)$ & & & & & \\
\hline $\begin{array}{l}\text { Outlets with alcohol } \\
\text { advertisement }\end{array}$ & & & 0.619 & & & & \\
\hline 0 & $75(17.8)$ & 1.00 & & & & & \\
\hline 1 & $81(22.0)$ & $1.71(0.66 ; 4.43)$ & & & & & \\
\hline $2-7$ & 48 (15.9) & $1.20(0.47 ; 3.07)$ & & & & & \\
\hline $\begin{array}{l}\text { Outlets with warning } \\
\text { sign forbidding sale } \\
\text { for minors }\end{array}$ & & & 0.314 & & 0.013 & $\S$ & 910.75 \\
\hline 1 & $120(17.6)$ & 1.00 & & 1.00 & & & \\
\hline 2 & $64(21.4)$ & $1.55(0.69 ; 3.48)$ & & $0.86(0.63 ; 1.18)$ & & & \\
\hline 3 & $20(16.6)$ & $1.37(0.56 ; 3.34)$ & & $0.59(0.32 ; 1.09)$ & & & \\
\hline $\begin{array}{l}\text { Closest alcohol } \\
\text { outlet }(\mathrm{m})\end{array}$ & & & 0.003 & & 0.000 & & \\
\hline $0-100$ & $99(21.5)$ & 1.00 & & 1.00 & & & \\
\hline $101-250$ & $93(21.4)$ & $0.85(0.44 ; 1.65)$ & & $0.83(0.62 ; 1.11) \S \S$ & & & \\
\hline 251 or more & $12(3.4)$ & $0.15(0.05 ; 0.45)$ & & $0.29(0.17 ; 0.48) \S \S$ & & & \\
\hline \multicolumn{8}{|l|}{$\begin{array}{l}\text { Distance from city } \\
\text { ground zero }(\mathrm{km})\end{array}$} \\
\hline $1.6-5.6$ & $104(26.5)$ & 1.00 & & & & & \\
\hline $5.7-8.2$ & $54(18.5)$ & $0.62(0.25 ; 1.57)$ & & & & & \\
\hline 8.3 or more & $46(12.1)$ & $0.39(0.17 ; 0.90)$ & & & & & \\
\hline
\end{tabular}

95\%Cl: 95\% confidence interval; AIC: Akaike information criterion; ICC: intraclass correlation coefficient; OR: odds ratio.

* Wald's test;

** Adjusted for demographic variables (sex and age);

*** Adjusted for demographic variables, shift and work;

\# Adjusted for demographic variables, shift, work and health related behaviors;

\#\# Adjusted for demographic variables, shift, work, health related behaviors, income per capita and demographic density;

\#\#\# Adjusted for demographic variables, shift, work, health related behaviors, income per capita, demographic density and school size;

§ICC values and confidence interval negligible;

$\S \S$ Adjusted for demographic variables, shift, work, health related behaviors, income per capita, demographic density, school size, distance from closest outlet and density of outlets with a warning sign forbidding sale to minors. 
In the adjusted model, a lesser chance of alcohol use was verified in the adolescents who attended schools that did not have any alcohol outlet in the neighborhood open during schools hours $(\mathrm{OR}=$ $0.15 ; 95 \% \mathrm{CI}: 0.05 ; 0.45)$; the use was higher in adolescents that attended schools with a 1.000 or more students ( $\mathrm{OR}=2.54$; 95\%CI: $1.50 ; 4.31$ ) (Table 2 ).

The ICC values varied from 0.18 a 0.01 , lowering progressively with every incorporated model. In the same way, the values of AIC and BIC were also lowered (Table 2).

\section{Discussion}

This study investigated the association of alcohol use by adolescents of public schools of Curitiba and the availability of alcohol outlets. The results showed that the alcohol use is associated with individual-level factors like an older age, working, having smoked before, and variables of the neighborhoodlevel such a bigger school and a smaller distance between the school and the closest alcohol outlets.

Of the adolescents that participated in the research $18.4 \%$ reported having used alcohol, which is lower than the numbers presented by ERICA for adolescents of Curitiba (26.7\%) and PeNSE 2015 for students of the 9th grade of public schools of Curitiba (24.3\%), in which most of the subjects were between 13 and 15 years old. This difference might be explained by the measurements, specifically, the question used in this survey (at least one dose used in an average week), while in PeNSE the question was about the use over the last 30 days 10 . These data are even more worrisome if considered that only $2 \%$ of the sample was 18 years or more, and that the average age of first contact with alcohol in Brazil is 14 years old 10 .

There was no significant difference of alcohol use between genders. Data from ERICA for adolescents of Brazil showed no difference by gender however for adolescents of Curitiba showed that girls (28.6\%) have a higher use than boys (24.9\%) 5. For this reason, the similar prevalence for boys and girls should be highlighted, considering that changes in use patterns by gender happened in the last five years, such as first contact with alcohol at a younger age and higher indexes of alcohol experimentation and current use by girls 9,10 . This change may be related to gender identity questions, as well as their own adolescence and a tendency for reaching maturity faster for girls 25 .

Higher chances of alcohol use by older subjects were demonstrated by the study, results which are consistent with other surveys 10,25. This can be explained by the autonomy and some level of economic independence acquired by adolescents over the years, as well as more friends and interactions with people from different ages, not forgetting that second most reported way of obtaining alcoholic beverages by adolescents were through friends 10 .

The adolescents who worked had a higher chance of having a regular alcohol use, even after adjusted for age. Working adolescents may be more exposed to alcoholic beverages because the work environment is composed mainly by adults; they are under a higher amount of stress and, besides that, the fact that they earn their own money gives them a higher acquisitive power, facilitating the purchase of drinks 26,27 .

Among the health-related behaviors, there was a significant association between the use of alcohol and smoking. The simultaneous exposition to risk behaviors has been described in literature 10,26, meaning that when they start using one substance the risk of using other substances increases 26,28. In that way, it is important to know and investigate, also, the main risk factors related to smoking, which are age, peer influence, parental education, parents who smoke and absence of supervision by the family 26,29 .

This study corroborated the association between alcohol use and a higher number of on-premises alcohol outlets, although the adjusted model lost its statistical significance. Researches in Australia, New Zealand, Switzerland and the United States show a positive relationship between alcohol use by adolescents and a higher density of on-premises alcohol outlets 16,17,30,31,32.

A lower alcohol use was observed among adolescents who attended a school in which the closest alcohol outlet was located further than $250 \mathrm{~m}$ away. In view of that fact, the importance of incorporating the new strategies such as policies regulating alcohol use, since they are effective strategies with scientific support and a low cost, and that they can target mainly vulnerable groups like the adolescents, should be emphasized. Among those strategies are setting a minimum distance of outlets by zoning laws and the regulation of prices and taxes 33 . 
In this study, lower chances of alcohol use and attending schools in which the neighborhood did not have any alcohol outlets in a radius of $250 \mathrm{~m}$ were observed, however, differently from other studies the association with the density of alcohol outlets was not confirmed 17,18 .

Through in loco mapping it was possible to ascertain, in some neighborhoods, the existence of alcohol outlets in the school's block (open during school hours). Brazilian cities such as Londrina (Paraná State) and São Paulo have approved new regulations establishing a minimum distance between places that sell alcohol and schools, since this measure has been shown in some investigations as having potential to reduce the prevalence of alcohol use. Reducing the exposure and the availability of alcohol in the neighborhood increases costs, which is an important aspect when limiting access for adolescents 34,35 . The findings of this research evidence the need to rethink the exposure of adolescents to alcohol outlets around schools. Even if such places forbid underage entrance (e.g.: pubs) and when the sale is forbidden by law, adolescents may acquire them directly or through the help of an adult, older friends, and family, as has been shown in some Brazilian studies 9,10.

Literature recognizes that physical and social characteristics of the environment play an important role in alcohol use pattern 14,34,35. Therefore, the enforcement of Law n. 8,069 (Child and Adolescent Statute), is necessary, as is providing training for those working at alcohol outlets, as a means to limit the social availability of alcohol for adolescents 33 . This can be accomplished by verifying identification documents and supervising the non-use even when they are accompanied by adults.

In school neighborhoods located in UHDs with a higher income and demographic density, a higher use of alcohol by adolescents was confirmed, but both lost their significance in the adjusted model. The school's neighborhoods characteristics typically reflect certain socioeconomic aspects of students' families living in the area, considering that the Paraná State Education Secretary uses a georeferencing system that enrolls students in schools closest to their residencies 36 . Although it was not possible to access the data of students' addresses, in our study $63.6 \%$ reported taking between 0 to 20 minutes walking from home to school (data not shown).

Because of that, the higher OR for alcohol use among adolescents that live in higher income neighborhoods (income per capita of BRL 854.0-2104.6), might be explained by a higher purchase power due to the better economic status of the families. That is demonstrated in a bigger financial source, which amounts to a lower relative cost compared to adolescents from poor neighborhoods 37 . Recent studies showed that a better parental socioeconomic status is related to a higher risk of alcohol use, while other studies did not find such a association $36,37,38,39$.

The variable school size was statistically significant in the adjusted model, meaning that the bigger the school the higher the chance of alcohol use, which can be related to the school distribution around the city: the biggest schools are closer to the city center where alcohol availability is higher. Central schools can have students from many different regions, facilitating the exposure to alcohol, even for students who live in poor neighborhoods. In addition, students who attend bigger schools may have more contact with older adolescents, which can increase the social availability of alcoholic beverage.

This study has some limitations that should be considered. The first one concerns other individual-level information such as sources of alcohol access, peer influence and parents' characteristics that were not collected during the study even though they are associated with alcohol use in adolescents. The second is that the area considered for the circular perimeter around the school was smaller compared to other available studies, wherein the area usually $1 \mathrm{~km}$ or more 14,15 , making comparisons more difficult. Despite that, we found associations between the school neighborhood and alcohol use among adolescents, and such a smaller area would be more feasible to policymakers implement actions. However, as school areas did not overlap in our study, it is possible that students are exposed to other school neighborhoods, which may only be addressed by spatial analysis. Third, the prevalence of alcohol use may be underestimated or even overestimated, since the questionnaire could be a source of embarrassment for the students, and memory may affect the results, although the fact that they filled the survey themselves helps reduce this problem.

On the other hand, given the few studies about the subject in Brazil, this study contributes to understanding the association between health-related behavior and school neighborhoods, further bringing information to help elaborate interventions aiming to reduce alcohol use among adolescents and instigate interest in the subject for the development of new studies. As a way of mitigating the lim- 
itations, while the questionnaire was being applied the researchers answered doubts and reinforced the anonymity of the survey. Even though the buffer area was smaller than in other studies, an in loco mapping of the evaluated areas was conducted by walking each street, recording each food or beverage outlet, which allowed up-to-date information to be collected regarding all the establishments that sold any kind of alcoholic beverage, that is, the data was evaluated inside the stores and not through listings, and from the criteria of selling alcohol or not. In addition, other information was collected like the presence of advertisement, the existence of warning signs forbidding the sale of alcohol to minors and prices. Furthermore, the selected schools were evenly distributed around the city.

The results of research conducted in the school environment provides tools that can be used in the implementation of public policies for the promotion of health and prevention addressed to the targeted public. On the other hand, it is important to highlight that the use of alcohol by adolescents is a complex subject in which many factors interact that were not included in this study (peer influence, family factors and neighborhood aspects). Future studies can include such factors as well as environmental aspects to better comprehend the effects of the commercial availability of alcohol and its effects on alcohol use in adolescents. Other tools could also be incorporated for analysis such as geoprocessing software.

\section{Conclusion}

Individual-level factors such as being older, working and having smoked before, and school neighborhood aspects such as a bigger school size and smaller distance to alcohol outlets were statistically associated with alcohol use by adolescents. Existence of alcohol outlets in the school's neighborhood that were open during school hours was verified.

We recommend that activities to train the owner and workers of alcohol outlets be performed, since they can contribute to lower alcohol use, as it limits the social and commercial availability of alcohol 33. In the same way, implementing regulatory policies concerning access to alcohol such as zoning laws and regulating alcohol prices is of utmost importance. 


\section{Contributors}

L. S. Cardoza participated in the study design, analysis and interpretation, writing of the manuscript, critical review and approval of the final version. C. O. Machado and C. T. Santos contributed in the data collection, analysis, critical review of the manuscript and approval of the final version. D. A. Höfelmann participated in the study design, data collection, analysis and interpretation, critical review of the manuscript and approval of the final version.

\section{Additional informations}

ORCID: Loren Salazar Cardoza (0000-0002-68898377); Christiane Opuszka Machado (0000-00021676-4342); Clara Telles dos Santos (0000-00033802-7113); Doroteia Aparecida Höfelmann (00000003-1046-3319).

\section{Acknowledgments}

We would like to thank the health professionals, students and people from the community who participated in the study. This study was supported by the Federal University of Paraná through scholarships to undergrad students of the Scientific Initiation Program, and by means of transport for the researchers in order to perform data collection. This study did not receive any specific funding from public, commercial of philanthropic institutions.

\section{Refererences}

1. Winstock A, Barrat M, Ferris J, Maier L. Global Drug Survey 2017. London: Global Drug Survey; 2017.

2. Johnston L, Miech R, O’Malley P, Bachman G, Schulenberg J, Patrick M. Overview key findings on adolescent drug use. Washington DC: National Institutes of Health; 2018.

3. World Health Organization. Global status report on alcohol and health 2018. Geneva: World Health Organization; 2018.

4. Organización de los Estados Americanos. Informe sobre uso de drogas en las Ámericas 2015. Washington DC: Organización de los Estados Americanos; 2015.

5. Coutinho ESF, França-Santos D, Magliano ES, Bloch KV, Barufaldi LA, Cunha CF, et al. ERICA: patterns of alcohol consumption in Brazilian adolescents. Rev Saúde Pública 2016; 50 Suppl 1:8s.

6. Instituto Brasileiro de Geografia e Estatística. Pesquisa Nacional de Saúde do Escolar 2013. Rio de Janeiro: Instituto Brasileiro de Geografia e Estatística; 2015.

7. Pechansky F, Szobot CM, Scivoletto S. Uso de álcool entre adolescentes: conceitos, características epidemiológicas e fatores etiopatogênicos. Rev Bras Psiquiatr 2004; 26:14-7.

8. Galduróz JCF, Sanchez ZM, Opaleye ES, Noto AR, Fonseca AM, Gomes PLS, et al. Fatores associados ao uso pesado de álcool entre estudantes das capitais brasileiras. Rev Saúde Pública 2010; 44:267-73.

9. Instituto Brasileiro de Geografia e Estatística. Pesquisa Nacional de Saúde do Escolar 2012. Rio de Janeiro: Instituto Brasileiro de Geografia e Estatística; 2013.

10. Instituto Brasileiro de Geografia e Estatística. Pesquisa Nacional de Saúde do Escolar 2015. Rio de Janeiro: Instituto Brasileiro de Geografia e Estatística; 2016.

11. Rodríguez García FD, Sanchiz Ruiz ML, Bisquerra Alzina R. Consumo de alcohol en la adolescencia: consideraciones médicas y orientaciones educativas. Salud Ment 2014; 37:25560.

12. Jorge KO, Ferreira RC, Ferreira E, Vale MP, Kawachi I, Zarzar P. Binge drinking and associated factors among adolescents in a city in southeastern Brazil: a longitudinal study. Cad Saúde Pública 2017; 33:e00183115.

13. Scribner RA, Mason KE, Simonsen NR, Theall $\mathrm{K}$, Chotalia J, Johnson S, et al. An ecological analysis of alcohol-outlet density and campusreported violence at 32 U.S. colleges. J Stud Alcohol Drugs 2010; 71:184-91.

14. Larsen K, To T, Irving HM, Boak A, Hamilton HA, Mann RE, et al. Smoking and bingedrinking among adolescents, Ontario, Canada: does the school neighbourhood matter? Health Place 2017; 47:108-14. 
15. Bryden A, Roberts B, McKee M, Petticrew M. A systematic review of the influence on alcohol use of community level availability and marketing of alcohol. Health Place 2012; 18:349-57.

16. Kuntsche E, Kuendig H, Gmel G. Alcohol outlet density, perceived availability and adolescent alcohol use: a multilevel structural equation model. J Epidemiol Community Health 2008; 62:811-6.

17. Rowland B, Toumbourou JW, Satyen L, Tooley G, Hall J, Livingston M, Williams J. Associations between alcohol outlet densities and adolescent alcohol consumption: a study in Australian students. Addict Behav 2014; 39:282-8.

18. Shih RA, Mullins L, Ewing BA, Miyashiro L, Tucker JS, Pedersen ER, et al. Associations between neighborhood alcohol availability and young adolescent alcohol use. Psychol Addict Behav 2015; 29:950-9.

19. Pasch KE, Hearst M, Nelson M, Forsyth A, Lytle L. Alcohol outlets and youth alcohol use: exposure in suburban areas. Health Place 2009; 15:642-6.

20. Instituto Paranaense de Desenvolvimento Econômico e Social. Perfil avançado do município de Curitiba. Curitiba: Instituto $\mathrm{Pa}$ ranaense de Desenvolvimento Econômico e Social; 2018.

21. Silva J. Estágios de mudança de comportamento para atividade física em adolescentes: prevalência e fatores associados [Dissertação de Mestrado]. Florianópolis: Universidade Federal de Santa Catarina; 2015.

22. Centers for Disease Control and Prevention. Behavioral risk factor surveillance system questionnaire. Atlanta: Centers for Disease Control and Prevention; 2016.

23. World Health Organization. Self - help strategies: for cutting down or stopping substance use, 2010. Geneva: World Health Organization; 2010.

24. Instituto Brasileiro de Geografia e Estatística. Unidades de desenvolvimento humano. Rio de Janeiro: Instituto Brasileiro de Geografia e Estatística; 2013.

25. Malta DC, Machado IE, Porto DL, Silva M, Freitas P, Costa AW, et al. Alcohol consumption among Brazilian Adolescents according to the National Adolescent School-based Health Survey (PeNSE 2012). Rev Bras Epidemiol 2015; 24:203-14.

26. Souza DPO, Areco KN, Silveira F. Álcool e alcoolismo entre adolescentes da rede estadual de ensino de Cuiabá, Mato Grosso. Rev Saúde Pública 2005; 39:585-92.

27. Reis DC, Almeida TA, Miranda MM, Alves RH, Madeira A. Health vulnerabilities in adolescence: socioeconomic conditions, social networks, drugs and violence. Rev Latinoam Enferm 2013; 21:586-94.
28. Elicker E, Palazzo L, Aerts DR, Alves GG, Câmara S. Uso de álcool, tabaco e outras drogas por adolescentes escolares de Porto Velho-RO, Brasil. Epidemiol Serv Saúde 2015; 24:399410.

29. Menezes AH, Dalmas JC, Scarinci IC, Maciel SM, Cardelli A. Fatores associados ao uso regular de cigarros por adolescentes estudantes de escolas públicas de Londrina, Paraná, Brasil. Cad Saúde Pública 2014; 34:774-84.

30. Huckle T, Huakau J, Sweetsur P, Huisman O, Casswell S. Density of alcohol outlets and teenage drinking: living in an alcogenic environment is associated with higher consumption in a metropolitan setting. Addiction 2008; 103:1614-21.

31. Paschall MJ, Grube JW, Thomas S, Cannon C, Treffers R. Relationships between local enforcement, alcohol availability, drinking norms, and adolescent alcohol use in 50 California cities. J Stud Alcohol Drugs 2012; 73:657-65.

32. Azar D. The association between alcohol outlet density and alcohol use among urban and regional Australian adolescents. Addiction 2016; 111:65-72.

33. Duailibi S, Laranjeira R. Políticas públicas relacionadas às bebidas alcoólicas. Rev Saúde Pública 2007; 41:839-48.

34. Chaloupka F. Public policies and private antihealth behavior. American Economic Review 1995; 85:45-9.

35. Springer F, Phillips J. The Institute of Medicine framework and its implication for the advancement of prevention policy, programs and practice. Santa Rosa: Center For Applied Research Solutions; 2007.

36. Secretaria da Educação e do Esporte. Georreferenciamento e transporte escolar. https:// www.nre.seed.pr.gov.br/modules/conteudo/ conteudo.php? conteudo $=514$ (accessed on Apr/2019)

37. Murayama H, Fujiwara Y, Kawachi I. Social capital and health: a review of prospective multilevel studies. J Epidemiol 2012; 22:17987.

38. Zarzar PM, Jorge KO, Oksanen T, Vale MP, Ferreira EF, Kawachi I. Association between binge drinking, type of friends and gender: a cross-sectional study among Brazilian adolescents. BMC Public Health 2012; 12:257.

39. Henkel D, Zemlin U. Social inequality and substance use and problematic gambling among adolescents and young adults: a review of epidemiological surveys in Germany. Curr Drug Abuse Rev 2016; 9:26-48. 


\section{Resumo}

O estudo teve como objetivo investigar a associação entre consumo de álcool por adolescentes e a disponibilidade de locais de venda de álcool na vizinhança das escolas públicas. Foi realizado um estudo transversal com a coleta de dados primários, usando como variáveis as características individuais dos alunos e da vizinhança da escola. Foi utilizado um modelo de regressão logística multiniveis para estimar a razão de chances (OR) com intervalo de 95\% de confiança (IC95\%) entre o consumo de álcool e as variáveis de exposição. Entre os adolescentes, 18,4\% (IC95\%: 13,2; 24,1) relataram consumo de álcool, que mostrou associação com as seguintes características individuais: idade acima de 18 anos, trabalho atual e história de tabagismo. Foi observado menor nivel de consumo de álcool em adolescentes matriculados em escolas localizadas a pelo menos 250 metros dos locais de venda de álcool (OR =0,29; IC95\%: 0,17; 0,48). São necessárias medidas para reduzir o uso de álcool entre adolescentes, levando em conta as características dos próprios alunos e da vizinhança da escola.

Consumo de Álcool por Menores; Vizinhaça; Análise Multinivel

\section{Resumen}

El objetivo de este estudio fue investigar la asociación entre el consumo de alcohol en adolescentes y la disponibilidad de establecimientos para la venta de alcohol en las cercanías de las escuelas públicas. Se trata de un estudio transversal que se realizó recogiendo datos primarios, incluyendo variables en el nivel individual, así como las relacionadas con el vecindario. Se realizó una regresión logística multinivel para estimar la odds ratio - OR (intervalo de 95\% de confianza - IC95\%), en el caso del consumo del alcohol con las variables de exposición. Un 18,4\% (IC95\%: 13,2; 24,1) de los adolescentes informaron haber consumido alcohol, lo que estaba asociado con variables en el nivel individual tales como: tener 18 años o más edad, estar trabajando y haber fumado antes. Se observó un consumo más bajo de alcohol entre adolescentes de escuelas que estaban localizadas a $250 \mathrm{~m}$ o más de los establecimientos de venta de alcohol $(\mathrm{OR}=$ 0,29; IC95\%: 0,17; 0,48). Las acciones para reducir el consumo de alcohol entre adolescentes deberían tener en consideración las características de los estudiantes y del barrio en el que están ubicadas las escuelas.

Consumo de Alcohol en Menores; Vecindario; Análisis Multinivel
Submitted on 05/Apr/2019

Final version resubmitted on 29/Feb/2020

Approved on 12/Mar/2020 